\title{
ACTIVATION OF ONCOGENES BY KADON PROGENY AND X-RAYS
}

\author{
C. Clifton Ling, Ph.D. \\ Medical Physics Department \\ Memorial Sloan Kettering Cancer Center \\ 1275 York Avenue \\ N.Y. N.Y. 10021 \\ Tel. No. 212.639-8301 \\ $\mathrm{DOE} / \mathrm{ER} / 60903--2$
}

\section{PROJECT OUTPUT}

DE91 001667

\section{Recent Accomplishments}

\section{REC Transfected with Activated Oncogenes}

The introduction of an activated c-myc or c-Ha-ras oncogene caused the REC to show a parial transformed phenotype. Specifically, the parially transformed cell lines (REC:myc and REC:ras) exhibited altered morphology (described below), longer lifespan (about 5 passages for primary cells, and $>20$ passages for transfected cells), shorier cycle doubling time $(12-25 \mathrm{hr}$ for transfected cells, $40 \mathrm{hr}$ for primary REC), and higher plating efficiency (about $30 \%$ for transfected cells, and <5\% for primary cells).

The REC:myc exhibited a fibroblastic morphology with an orderly growth pattern, while the primary REC showed variation in morphology and randomness in growth. Cells derived from ras transfection are generally smaller, have a more uniform appearance, and grow to aigher density, than the primary cells.

\section{Alphe Farticle Irradiation and Dosimetry}

During the past year the apparatus for irradiating cells with $6 \mathrm{MeV}{ }^{4} \mathrm{He}^{++}$particles from a CC15 cyclotron at this Institute was designed, constructed, tested and utilized. Methods were developed for absorbed dose determination and beam monitoring during irradiation.

The components of the cyclotron apparatus are as follows. A $0.057 \mathrm{~mm}$ thick aluminum foil is located after the steering and focusing magnets at the entrance to a $1.5 \mathrm{~m}$ long evacuated beam pipe. The purpose of this foil is to broaden the beam and to degrade the beam from $15.8 \mathrm{MeV}$ to $10.6 \mathrm{MeV}$. The sample chamber entrance window of $0.0127 \mathrm{~mm}$ of titanium also serves as the beam pipe exit window and supports the vacuum. The air column from the entrance window to the surface of the Petri dish is $3.2 \mathrm{~cm}$. The intial Al foil thickness was determined using continuous slowing-down approximation and published stopping powers to produce $6 \mathrm{MeV}$ beam at the cells after the further degradation by the titanium foil and air. An insulated ring monitor was placed $10 \mathrm{~cm}$ before the beam pipe exit window. This monitor was calibrated against a specially designed Faraday cup mounted on the sample chamber with the aperture located at the cell position. For Faraday cup measurements, the sample chamber and cup were at $1 \mathrm{mTorr}$. This procedure provided the charge to the cells per monitor charge collected during irradiation. The 
dose to the cells was determined by the particle fluence and stopping power. A ring magnet was placed just behind the titanium window to deflect electrons produced in the window away from the cup aperture. For the calibration a thickness of aluminum foil equivalent to the air in the sample chamber was placed just in front of the ring magnet. This foil changed the fluence by only $5 \%$.

The energy of the particles incident on the initial aluminum degrading foil and at the cells after full degradation was verified by a measurement of the range in aluminum. It was necessary to reduce the beam current for the cell irradiation to about $100 \mathrm{pA}$. Operation under this low current is not stable. The use of the monitor and frequent calibration made before, midway and at the end of each set of cell irradiations made for reproducibility.

\section{Alpha Particle RBE for Cellular Survival and Transformation}

Primary REC, REC:myc and REC:ras have been irradiated with $137 \mathrm{Cs}$ gamma ray or with the $6 \mathrm{MeV}{ }^{4} \mathrm{He}^{++}$particles. Survival curves were measured for all the cell lines. Transformation frequencies were measured at 6 Gy with gamma ray cells, and at 2 and $6 \mathrm{~Gy}$ for $6 \mathrm{MeV}$ alpha particles. Irradiation with gamma rays were at dose rate of approximately $1 \mathrm{~Gy} / \mathrm{min}$. Irradiation times for the cyclotron ranged from about 10 sec to $2 \mathrm{~min}$. For experiments, log phase cells attached to Petri dishes were used. For irradiations with gamma rays, cells were plated onto the whole surface of a $60 \mathrm{~mm}$ dish. For irradiation with alpha particles, the dish had to be held vertical in the sample chamber. To prevent artefacts arising from cells at the bottom corner shielded from radiation by the residual liquid layer, we adopted the following precaution. Cells were plated into polyethylene rings of $3 \mathrm{~cm}$ diameter centered in the $60 \mathrm{~mm}$, such that there is no cells at the edge of the petri dish. Just prior to irradiation the ring was removed and $2 \mathrm{ml}$ of medium was added to the dish, and then the dish was drained and aspirated at the lower corner with a Pasteur pipette. Wetting the dish after removing the ring provided a uniformly wet surface over the whole dish to prevent drying during the irradiation procedures. Draining and aspirating at the lower corner with a Pasteur pipette removed any unattached cells. After irradiation, cells were trypsinized and replated using appropriate dilutions for measurementsof survival fractions or for transformation frequency.

For RBE determination, survival curves were measured for particle and gamna irradiation in the same experiment to permit a direct comparison. RBE, at $10 \%$ survival level, was about 2.9. The value at other survival levels are slightly different due to the different shapes of the survival cur'es for high and low LET radiations. For gamma rays, transformation frequency per survivor at $6 \mathrm{~Gy}$ was found to be $1.8 \times 10^{-5}$ for the oncogene-transfected cells. For $6 \mathrm{MeV}{ }^{4} \mathrm{He}^{++}$particles, the transformation per surviving REC:myc cell was about $4 \times 10^{-5}$ at 2 Gy and $2 \times 10^{-5}$ at $6 \mathrm{~Gy}$. The transformed foci resemble the type III foci of transformed mouse cell lines (Reznikoff 73). Transformed colonies were picked with the aid of a cloning cylinder and grown in T-75 flasks for further analysis. No transformants were observed in $10^{5}$ colonies of primary REC treated with 600 cGy of X-rays, nor in any of the unirradiated REC:myc or REC:ras with up to $10^{5}$ colonies observed.

\section{Anchorage Independent Growth and Tumor Induction}

For evaluation of tumorigenic potential, cells were tested for ability to form colonies in semi-solid media (i.e. anchorage independent growth), and to induce tumors in 
animal hosts. As a positive control, cells transfected with both the myc and the ras oncogenes were used.

To test for tumor induction, $5 \times 10^{6}$ cells were injected subcutaneously into nude mice. Transformed REC containing both the c-myc and the c-Ha-ras oncogenes were used as a positive control and produce large tumors within a week of inoculation. The animals were monitored twice weekly for the appearance of tumors and sacrificed before the tumors reached a size of $1.0 \mathrm{~cm}$. Neither primary cells, REC:myc nor REC:ras produced any tumors with up to 6 dmonths of observation. However, when transformed by X-ray or $\mathrm{He}-4$, some derivatives of both REC:myc and REC:ras form tumors in nude mice.

\section{Molecular Analysis}

For molecular analysis, genomic DNA and mRNA from the various cell lines were isclated and analyzed. Southern hybridization analysis was performed to (i) verify the presence of the transfected oncogeres in the respective cell lines, and (ii) detect rearrangements and amplifications of transfected oncogenes and specific endogenous oncogenes. RNA northern blots were performed to determine the expression levels of specific oncogenes.

Our initial study focussed on the myc and ras oncogenes, becsuse they act cooperatively, and both have been implicated in radiation-induced carcinogenesis (Mizuki 85, Guerrero 84, Sawey 87). In particular, the presence or absence of mutations in the potentially complementing oncogene was determined (e.g. myc rearrangements in X-ray transformed REC:ras). These Southern analyses would also ascertain any gross structural mutations induced in the transfected oncogene by $X$ rays.

In the case of REC:myc+X our data showed that there were no rearrangements or amplifications of either the transfected or endogenuus c-myc. In addition, tests for $\mathrm{c}-\mathrm{Ha}$-ras, c-Ki-ras, $\mathrm{N}$-ras and raf, oncogenes which complement myc in transforming certain cell lines, were negative for rearrangements or amplifications. This is perhaps not surprising since point mutations, the most common pathway of ras activation, are difficult to detect by Southern analysis and do not generally alter expression. For this reason we performed the C3H10T1/2 transformation assay, as described below. We further propose to ascertain the actual mutation in any rat ras oncogenes detected in the C3H10T1/2 transformants by the polymerase chain reaction method (PCR).

Similarly, there were no detectable changes in the endogenous or transfected c-Haras for X-ray transformed REC:ras. In addition, the nuclear oncogenes; myc, myb, fos, and p53 were also tested and showed no amplifications or rearrangements.

Northern analysis of cytoplasmic RNA from the X-ray transformed REC:myc cells displayed no change in the expression levels of c-myc, c-Ha-ras, c-Ki-ras, N-ras, or $c$-raf. In the case of, X-transformed REC:ras, there were no alterations in expression level of c-Ha-ras, or the potentially complementing nuclear oncogenes myc, myb, fos or p53

\section{DISCLAIMER}

\footnotetext{
This report was pr'pared as an account of work sponsored by an agency of the United States Government. Neither the United States Government nor any agency thereof, nor any of their emp!nyee., inakes any warranty, express or implied, or assun os any legal liability or responsibility for the accuracy, completeness, or usefulness of any information, apparatus, produci, or process disclosed, or represents that its use would not infringe privately owned rights. Reference herein to any specific commercial prorluct, process, or service by trade name, trademark, manufacture:, or otherwise does not necessarily constitute or imply its endorsement, recommendation, or favoring by the United States Government or any agency thereof. The views and opinions of authors expresced herein do not zecessarily state or reflect those of the United States Government or any agency thereof.
} 


\section{C3HIOTl/2 Assay for Dominant Oncogenes}

To assay for activated ras oncogenes (or ras-like oncogenes), C3H20T1/2 cells were transfected with high molecular weight DNA from X-ray transformed REC:myc, and plated for foci formation. This assay is esssentially the same as the more commonly uscd NIH3T3 transfection assay, the main difference being that $\mathrm{C} 3 \mathrm{H} 10 \mathrm{~T} 1 / 2$ cells have a lower frequency of spontaneous transformation than NIH3T3 cells. Out of 5 clones tested, DNA from 2 isolates produced the transformed phenotype in recipient C3H10T1/2 cells. Southern analysis, is being carried out on DNA from the transformed $\mathrm{C} 3 \mathrm{H} 10 \mathrm{~T} 1 / 2$ cells to determine if rat ras oncogenes can be detected. This will demonstrate whether dominant transformation was caused by non-ras, novel oncogenes. These results may be similar to those of Borek et. al. (Borek 87) in which they found transforming properties in X-ray transformed C3H10T1/2 and NIH3T3 cell lines that could not be attributed to ras oncogenes.

\section{Karyotypic Analysis of REC:myc $+X$ Isolates}

We have begun cytogenetic analysis of REC, the transfected and X-irradiated derivatives. Dr. Vijayalaxshmi has shown in preliminary studies of conventional chromosome metaphase analysis that Primary REC and REC:myc have the normal modal chromosome number of 42, while the first clone of REC:myc+X to be studied has a modal chromosome number of 41 . The G-banded karyotypes of REC and REC:myc were also normal in contrast to REC:myc+X which shows chromosome loss. This result is intriguing because it suggests that chromosome loss may play a role in the development of the transformed phenotype. Several isolates are currently under study to determine if there are any trends in chromosome loss in similarly derived cell lines. REC:ras $+X$ will also be investigated.

\section{EJ ras Oncogene vs. rasVal Oncogene}

Recently Cohen and Levinson (88) reported that the EJ ras oncogene (used in our initial work) has two mutations: the first is on codon 12 of the first exon which causes a glycine to valine substitution, and the second is a single A-G substitution in the last intron at position 2719. The latter mutation causes EJ ras to be ten times more efficient than other ras oncogenes at inducing foci in Rat-1 cells. This finding means that the co-operation between c-myc and EJ ras in transforming primary REC involves at least three mutational events, and impacts on our strategy to study the role of radiation in multistep carcinogenesis. This motivated us to extend the work of Cohen and Levinson to study the importance of the ras intron mutation in the transformation of primary rat embryo cells.

For this study, we constructed a hybrid of the c-Ha-ras oncogene which contained only the mutation at codon 12 that results in the gly $\rightarrow>$ val substitution, but without the intron $A \rightarrow G$ substitution at position 2719 . This ras oncogene hybrid is designated ras VAL. The function of this construct was compared to that of EJ ras (rasEJ) in the transformation of primary rat embryo cells (REC), via cotransfeciion with the myc oncogene. We find that both the exon and intron mutations of ras are necessary for efficient transformation of primary rat embryo cells. The detailed procedures and results of this study is reported in the appended manuscript, which has been submitted for publication. The following is a brief summary of the results.

We first verified the activity of the rasVAL construct, in comparison with rasEJ, by transfection into NIH3T3 cells. The NIH3T3 assay have been shown to be susceptible 
to transformation by all ras oncogenes tested (Shih 81). Both rasVAL and rasEJ were equally efficient at inducing foci in NIH3T3 cells. Then, the ability of the rasVAL oncogene to cooperate with myc in transforming primary rat embryo cells was compared to that of rasEJ, using the co-transfection method previously described. Both the rasEJ and the rasVAL constructs were capable of cooperating with the myc oncogene to cause transfected REC to form foci, but rasVAL was much less efficient. In contrast, the use of different constructs of myc in the transfection experiments did not alter the transformation frequency. Experiments conducted with the myc cDNA (MLVmyc) gave essentially the same results as those performed using the cmyc gene in pM21myc.

Cells derived from transfection with rasVAL or rasEJ exhibited other phenotypic differences. Isolates from cells cotransfected with myc and rasVAL were less capable of anchorage independent growth and less efficient in forming tumors in nude mice. Independent isolates of rasEJ transformants formed large foci in soft agar within a few days, with a frequency of $5-40 \%$. In contrast, rasVAL transformants form smaller foci, with a much lower probability, and require $2-4$ times as long to become visible.

All the rasEJ and rasVAL isolates generated tumors in nude mice, but with different kinetics. rasEJ transformants formed very large tumors in nude mice in a week or less following inoculation. In comparison, the rasVAL isolates formed tumors more slowly, with some isolates inducing large tumors at two weeks post inoculation, and the weakest ones requiring approximately three weeks. This suggests that the missense mutation of codon 12 of the ras oncogene is sufficient for tumorigenesis in cooperation with myc, but that the rate of tumor formation is dependent on the intron mutation.

Northern hybridization analysis suggest that the differences in anchorage independence and tumorigenicity may be due to the difference in level of expression of the ras oncogene. Together with Southern hybridization analysis, we learned that the level of ras expression was less dependent on the number of integrated copies of ras, but more on the presence of the intron mutation. For equivalent numbers of copies of rasEJ and rasVAL, the expression of rasEJ was much higher than rasVAL. These findings are in agreement with the study of Cohen and Levinson using Rat-1 cells (88).

Thus, we conclude that ras containing only the missense mutation exhibits lower expression but is still effective at inducing the transformed phenotype although at a much slower rate than ras containing the additional intron mutation. And thus, the effect of the intron mutation may primarily be on the kinetics with which the transformed phenotype is expressed.

\section{Radioresistance induced by Oncogenic Transformation}

As baseline data for radiation transformation study, we measured cell survival via clonogenic assay as a function of radiation dose from $250 \mathrm{kVp} \mathrm{X}$-rays. We were intrigued by the apparent differences in radiosensitivity of the transfected cell lines, particularly in comparison with the primary REC. At about the same time other investigators also reported similar findings. Our data in this area have been reported in an article; Radiat. Res. 120, 267-279. We summarize these results here. The data on REC:myc indicate that the incorporation of a myc gene into its genome may alter the radiosensitivity of REC. However, no additional alteration in 
radioresponse is observed in association with the $\mathrm{X}$-ray induced morphological changes.

Using primary REC, two REC:ras lines, and a REC:ras+X line derived from REC:ras A, we showed that transfection with the ras oncogene induces alteration in radiosensitivity. Both REC:ras A and REC:ras B are more radioresistant than the primary REC. As is the case for myc transfected cells, X-ray induced morpholngical changes do not further alter cellular radioresponse. A comparison of radioresponse of the primary REC and three REC:myctras cell lines gives the same conclusion, all the transfected lines are more radioresistant than the primary. REC. The degree of acquired radioresistance differs for the three cell lines, however.

To assess the possible influence of cell cycle distribution on the radiosensitivity of the different cell lines, (i) cytofluorimetric analysis is performed, and, (ii) survival probability is measured as a function of dose for plateau phase cells, in comparison with that obtained for cells in exponential growth phase. Results from the latter measurements indicate the same conclusions for cells in plateau phase.

Transfection of a single oncogene confers a degree of radioresistance, which may be augmented by the presence of a second oncogene. In analysing the cell cycle distribution data from cytofluorimetry, attention is directed to examine whether there is a larger $S$ phase population in radioresistant cells, i.e. those transfected with one or two oncogenes. Variations exist in the cell cycle distribution of the different lines, but there is no discernable correlation between radioresistance and a preponderance of $S$ phase population.

\section{PUBLICATIONS}

1. Radioresistance induced by oncogenic transformation. C. Clifton Ling and Brian Endlich. Radiation Research 120, 267-279 (1989).

2. Synergistic effect of the V-myc oncogene with $H$-ras on radioresistance.McKenna WG, Weiss MC, Endlich B, Ling CC, Bakanauskas VJ, Kelsten ML and Muschel RJ. Radiation Research $50,97-102,1990$.

3. The role of the $\mathrm{H}$-ras oncogene in radiation resistance and metastasis. McKenna WG, Weiss MC, Bakanauskas VJ, Sandler H, Kelsten ML, Biaglow J, Tuttle SW, Endlich B, Ling CC and Muschel RJ: Int. J. Radiation Oncology Biol. Phys. 18, 849-859, 1990.

4. Li CC, Ling CC, Endlich B and Mak JY: Thermal Response of oncogene-transfected rat cells: Cancer Research 50, 4515-4521, 1990

\section{REFERENCES}

Adams, J.M., Harris, A.W., Pinkert C.A., et. al. The c-myc oncogene driven by immunoglobulin enhancers induces lymphoid malignancy in transgenic mice. Nature $1985 ; 318: 533-8$.

Altschuler, B., Nelson, N., Kuschner, M. Estimation of lung tissue dose from the inhalation of radon and daughters. Health Phys. 1964; 10:1137.

Balmain, A., Pragnell, I.B. Mouse skin carcinomas induced in vivo by chemical carcinogens have a transforming Harvey-ras oncogene. Nature. 1983; 303:72-74.

Barreth, J.C. Cell culture models of multistep carcinogenesis. IARC-Sci-Publ. 1985; 58:181-202. 
Bender, M. Induced aberrations in human chromosomes. Am. J. Pathol. 1963; 43:26-

Berenblum, I. in Cancer, F.Becker, Ed. (Plenum, New York 1981) vol 1:451-84.

Blumberg, P.M., Delclos, K.B., Dunn, J.A., et. al. Phorbol ester receptors and the in vitro effects of tumor promotors. Ann. N.Y. Acad. Sci. 1983; 407:303-15.

Borek, C., Ong, A., Mason, H. Distinctive transforming genes in $\mathrm{x}$-ray-transformed mammalian cells. Proc. Natl. Acad. Sci. USA. 1987; 84:794-798.

Bouck, N.P., Benton, B.K. Loss of cancer suppressors, a driving force in carcinogenesis. Chem. Res. Toxicol. 1989; $2: 1-11$.

Brereton, H.D., Mathews, M.M, Costa, J., et al. Mixed anaplastic small-cell and squarnous-cell carcinoma of the lung. Arn. Intern. Med. 1978; 88:805-6.

Caims, J. Mutation selection and the natural history of cancer. Nature. 1975; 255:197-202.

Carney, D.N.. Bunn, P.A., Gazdar, A.F., et al. Selective growth in serum-free hormone-supplemented medium of tumor cells obtained by biopsy from patients with small cell carcinoma of the lung. Proc. Natl. Acad. Sci. USA 1981; 78:3185-9.

Capon D.J., Seeburg, P.H., McGrath, J.P., et al. Activation of Ki-ras-2 gene in human colon and lung carcinomas by two point different point mutations. Nature $1983 ; 304: 507-13$.

Cavanee, W.K., Dryja, T.P., Phillips, R.A., Benedict, W.F., Godbout, R., Gallie, B.L., Murphree, A.L,. Strong, L.C., White, R.L. Nature 1983; 305:779-84.

Cepko, C.L., Roberts, B.E., Mulligan, R.C., Construction and applications of a highly transmissible murine retrovirus shuttle vector. Cell 1984; 37:1053-62.

Chang, J.D., Billings, P., Kennedy, A.R. Reduction in c-myc expression is associated with antipain treatment of proliferating C3H10T 1/2 cells. Biochem. Biophys. Res. Comm. 1985; 133:830-835.

Cohen, B.L. Survey of one-year average Rn levels in Pittsburgh area homes. Health Phys. 1985; 49:1053-1059.

Coleman, C.N. Secondary neoplasms in patients treated for cancer: etiology and perspective. Rad. Res. 1982;

92:188-200.

Committee for a standardized karyotype of rattus norvegicus. Cytogenet. Cell Genet. 1973; 12:199-205.

Court-Brown, W.M., Doll, R. Brit. Med. J. 1965; 2:1327-1332.

Culp, L.A., Black, P.H., J. Viol. 1972; 9:611-620.

Dalla-Favera, R., Wong-Staal, F., Gallo, R.C. Onc gene amplification in promyelocytic leukemia cell line HL-60 and primary leukemia cells of the same patient. Nature. 1982; 299:61-64.

Davidson, R. and Geral P.S. 1976; Somatic Cell Genetics 2: 165-176.

Doniger, J., Di Paolo, J.A., Popescu, N.C. Transformation of Bloom's syndrome fibroblasts by DNA transfection. Science. 1983; 222:1144-1146.

Dotto G.P., Parada, L.F., Weinberg, R.A. Specific growth response of ras-transformed embryo fibroblasts to tumour promistors. Nature 1985; 318:472-5.

Duesberg, P.H., Retroviral transforming genes in normal cells? Nature 1983; 304:219-26. 
Fasano, O., Adrich, T., Tamanoi, F. et al., Analysis of the transforming potential of the human H-ras gene by random mutagenesis. Proc. Natl. Acad. Sci. USA. 1984; 81:4008-12.

Felgner, P. personal commurication (manuscript submitued, Proc. Natl. Acad. Sci. USA).

Fermandaz, A., Mondal, S., Heidelberger, C. Probablistic view of the transformation of cultured C3H/10T1/2 mouse embryo fibroblasts by 3-methylcholanthrene. Proc. Nau. Acad. Sci. USA. 1980; 77:7272-7276.

Geiser, A.G., Der, C.J., Marshall J.M. and Stanbridge, E.J. Suppression of tumorigenicity with continued expression of the c-Ha-ras oncogene in EJ bladder carcinoma - human fibroblast hybrid cells. Proc. Natl. Acad. Sci. 1986; 83: 5209-5213.

Gorman, C.M., Moffat, L.F., Howard, B.H. Recombinant genomes which express chloramphenicol acetyltransferase in mammalian cells. Molec. and Cellul. Biol. 1982; 2:1044-1051.

Gottlieb, L.S., Husen, L.A. Lung cancer among Navajo uranium miners. Chest. 1981; 81:449-452.

Green, A.R. Recessive mechanisms of malignancy. British Journal of Cancer. 1988; 58:115-121

Gruenert, D.C., Wilson, A.M. Widdicombe, J.H. et al. J. Cell. Biochem. 1987; 11A:58.

Guerrero, I., Calzada, P., Mayer, A. et al. A molecular approach to leukemogenesis:mouse lymphomas contain an activated c-ras oncogene. Proc. Nat. Acad. Sci. USA. 1984; 81:202-205

Guerrero, I., Killasante, A., Corces, V. et al. Activation of a c-k-ras oncogene by somatic mutation in mouse lymphomas induced by gamma radiation. Science. $1984 ; 225: 1159-1162$.

Hall, EJ. Radiobiology for the Radiologist. 1978; 2nd Ed.

Han, A., Elkind, M.M. Transformation of Mouse $\mathrm{C} 3 \mathrm{H} / 10 \mathrm{~T} 1 / 2$ cells by single and fractionated doses of $\mathrm{x}$-rays and fission-spectrum neutrons. Cancer Res. 1979; 39:123-130.

Hattori, S., Matsuda, M., Tateishi, R. et al. Oat cell carcinoma of the lung. Cancer. 1972; 30:1014.

Horacek, J., Placek, V., Sevc, J. Histologic types of bronchogenic cancer in relation to different conditions of radiation exposure. Cancer. 1977; 40:832.

Iliakis, G. Radiation induced potentially lethal damage: DNA lesions susceptible to fixation. Int. J. Radiat. Biol. Related Stud. Phys. Chem. Med. 1988, 53:541-584.

Jablon, S., Belsky J.L., Tachikawa, K. et al. Cancer in Japanese exposed as children to atomic bombs. Lancet. 1971; 1:927-932.

Johnson, B.E., Battey, J., Linnoila, I. et al. Changes in the phenotype of human small cell lung cancer cell lines after transfection and expression of the c-myc proto-oncogene. J. Clin. Invest. 1986; 78:525-532.

Kennedy, A., Caims, J., Little, J. Timing of the Steps in transformation of C3H 10T $1 / 2$ cells by X-irradiation. Nature. 1984; 307:85-86.

Kennedy, A., Fox, M., Murphy, G. et al. Relationship betwcen x-ray exposure and malignant transformation in C3H 10T $1 / 2$ cells. $1980 ; 77: 7262-7266$.

Kim, J.H., Chu, F.C.H., Woodward, H.Q., et al. Radiation induced sarcomas of bone following therapeutic radiation. Int. J. Rad. Onc. Biol. Phys. 1982; 9:107-110.

Kotin, P., Courington, D., Falk, H.L. Pathogenesis of cancer in a ciliated mucus-secreting epithelium. Amer. Rev. Respir. Dis. 1966; 93:Suppl.115. 
Kurzrock, R. Gallick, G.E., Gutterman, J.U. Differential expression of p21 ras gene products among histological subtypes of fresh primary human lung tumors. Cancer Res. 1986; 46:1530-4.

Kwok, W.W., Schuening, F, Stead, R.B., Miller, A.D., Retroviral transfer of genes into canine hemopoictic progenitor cells in culture: a model for human gene therapy. Proc. Natl. Acad. Sci. USA. 1986; 83:4552-5.

Land, H., Chen, A.C., Morgenstern, J.P. et al. Behavior of myc and ras oncogenes in transformation of rat embryo fibroblasts. 1986; Mol. Cell. Biol. 6:1917-1925.

Land, H., Parada, L.F., Weinberg, R.A. et al. Tumorigenic conversion of primary embryo fibroblasts requires at least two cooperating oncogenes. 1983; Nature. 304:596-602.

Lechner, J.F., LaVeck, M.A. J. Tissue Culture Methods. 1985; 9:43-48.

Lee, E.Y.H., Bookstein, R. et al. Molccular mechasnisms of retinoblastoma gene inactivation in retinoblastoma cell line Y79. 1988; Proc. Natl Acad. Sci. : 6017-6021.

Lee, V/H., Murphree, A.L., Benedict, W.F. 1984; Nature 309:458-460.

Levan, G. Nomenclature for G-bands in rat chromosomes. Hereditas. 1974. 77:37-52.

Liang, J.C., Kurzrock, R., Guilerman, J.U. et al. Trisomy 12 correlates with elevated expression of p21 ras in a human adenosquamous carcinoma of the lung. 1986; Cancer Genet. Cytogenet. 23:183-188.

Ling, C.C., Stickler, R., Schell M. et al The effect of hypoxic cell sensitizers at different irradiation dose rates. 1987; Radiation Research. 109: (In press).

McCuthan, J.H., Pagano, J.S. Enhancement of the infectivity of Simian Virus 40 deoxyribonucleic acid with diethyl-aminoethyl-dextran. J. Naul. Cancer Inst. 1968; 41:351-6.

Messing, J. New M13 vectors for cloning. Methods Enzymol. 1983; 101:20-73.

Miller, D.A., Der, V.G., Borek, C., Miller, OJ. The quinocrine fluorescent and geimsa banding karyotype of the rat rattus norvegicus, and banded chromosome analysis of transformed and malignant cell lines. Cancer Res. 1972; $32: 2375-2382$.

Milo, G.E., Noyes, I., Donahoe, J. et al. Neoplastic transformation of human epithelial cells in vitro after exposure to chemical carcinogens. Cancer Res. 1981a; 41:5096-5102.

Mizuki, K., Nose K., Okamoto, H., et al. Amplification of c-K-ras gene and aberrant expression of c-myc in WI38 cells transformed in vitro by gamma-irradiation. 1985; Biochem. Biophys. Res. Comm. 128:1037-1043.

Myrden, J.A., Hiltz, J.E. Breast cancer following multiple fluoroscopies during artificial pneumothorax treatment of pulmonary tuberculosis. Can. Med. Assoc. J. 1969; 100.1032-1034.

Nau, M.M., Brooks, B.J., Battey, J. et al. L-myc, a new myc-related gene amplified and expressed in human small cell lung cancer. Nature. 1985; 318:69-73.

NCRP Report No. 78. Evaluation of occupational and environmental exposures to radon and radon daughters in the United States. Natl. Council on Rad. Protect. and Measure. May 31, 1984.

Neel, B.G., Hayward, W.S., Robinson, H.L. et al. Avian leukosis virus-induced tumors have common proviral integration sites and synthesize discrete new RNAs oncogenesis by promoter insertion. 1981; Cell. 23:323-334.

Nero, A.V., Schwehr, M.B., Nagaroff, W.W. et al. Distribution of airborne radon-222 concentrations in U.S. homes. Science. 1986; 234:972-997. 
Neumann, E., Schaefer-Ridder, M., Wang, Y. et al. Gene transfer into mouse lymphoma cells by electroporation in high electric fields. EMBO J. 1982; 1:841-845.

Newbold, R.F., Overell, R.W. Fibroblast immortality is a prerequisite for transformation by EJ c-Ha-ras oncogene. Nawre. 1983; 304:648-651.

Nishikura, K., AR-Rushdi, A., Erikson, J. et al. Differential expression of the normal and translocated human cmyc oncogene in B cells. Proc. Natl. Acad. Sci. USA. 1983; 80:4822-4826.

Noda, M., Kitayama, H., Matsuzaki, T., Sugimoto, Y., Okayama, H., Bassin, RH., Ikawa, Y. Detection of genes with a potential for suppressing the transformed phenotype associated with activated ras genes. Proc. Natl. Acad. Sci. USA. 1989; 86:162-166.

Noda, M., Selinger, Z., Scolnick, E.M., Bassin, R.H. Proc. Natl. Acad. Sci USA. 1983; 80:5602-5606.

Oi, V.T., Morrison, S.L., Herzenberg, L.A., Berg, P. Immunoglobulin gene expression in transformed lymphoid cells. Proc. Natl. Acad. Sci. USA. 1983; 80:825-9.

Ozanne, B., Shum, A., Richards, C., et al. Evidence for an increase in EGF receptors in epidermal malignancies. Cancer Cells 1985; 3:41-9.

Penn, I. Second neoplasms following radiotherapy or chemotherapy for cancer. Am. J. Clin. Oncol. 1982; 5:8396.

Perry, R.P. Consequences of myc invasion of immunoglobulin loci: facts and speculations. Cell. 1983; 33:647649.

Pollack, R.E., Green, H., Todar, G.J. Proc. Natl. Acad. Sci USA. 1968; 60:126-131.

Reddy, E.P., Reynolds, R.K., Santos, E. et al. A point mutation is responsible for the acquisition of transforming properties by the T24 human bladder carcinoma oncogene. Nature. 1982; 300:149-152.

Rhim, J.S., Sanford, K.K,. Amstein, P., et al. Human epithelial cell carcinogenesis: combined action of DNA and RNA viruses produces malignant transformation of primary human epidermal keratinocytes. Carcinog. Compr.

Surv. 1985; 9:57-66.

Rhim, J.S., Fujita, J., Arnstein, P., et al. Neoplastic conversion of human keratinocytes by adenovirus 12-SV40 virus and chemical carcinogens. Science 1986; 232:385-8.

Roninson, I.B. Detection and mapping of homologous, repeated and amplified DNA sequences by DNA renaturation in agarose gels. Nucleic Acids Res. 1983; 11:5413-5431.

Ruley, H.E., Adenovirus early region $1 A$ enables viral and cellular transforming genes to transform primary cells in culture. Nature 1983; 304:602-606.

Saccomanno, G., Archer, R.P., Saunders, L.A. Lung cancer of uranium mines on the Colorado plateau. Health Phys. 1964; 10:1195.

Saccomanno, G., Archer, VE., Auerbach, O. et al. Histologic types of lung cancer among uranium miners. Cancer $1971 ; 27: 515-523$.

Sager, R. Genetic suppression of tumor formation. Advances in Cancer Research 1985; 44:43-68.

Sager, R., Tanaka, K., Lau, C.C. et al. Resistance of human cells to tumorigenesis induced by cloned transforming genes. Proc. Natl. Acad. Sci. USA. 1983; 80:7601-7605.

Saiki, R.K., Scharf, S., Faloona, F. et al. Enzymatic amplification of beta-globin genomic sequences and restriction site analysis for diagnosis of sickle cell anemia. Science. 1985; 230:1350-1354. 
Saksela, K., Bergh, J., Nilsson, K. Amplification of the N-myc oncogene in an adenocarcinoma of the lung. J. Cell. Biochem. 1986; 31:297-304.

Sawey, M.J., Hood, A.T., Burns, F.J. et al. Activation of c-myc and c-K-ras oncogenes in primary rat tumors induced by ionizing radiation. Molec. and Cellul. Biol. 1987; 7:932-935.

Schaefer R., Iyer J., Iten E., Nirkko A.C. Partial reversion of the transformed phenotype in HRAS-transfected tumorigenic cells by transfer of a human gene. Proc. Natl. Acad. Sci. USA. 1988; 85:1590-1594.

Scharf, S.J., Horn, G.T., Erlich, H.A. Direct cloning and sequence analysis of enzymatically amplified genomic sequences. Science. 1986; 233:1076-1078.

Schwab, M., Alitalo, K., Varmus, H.E. et al. A cellular oncogene (c-Ki-ras) is amplified, overexpressed, and located within karyotypic abnormalities in mouse adrenocortical tumor cells. Nature. 1983; 303:497-501.

Seifter, E.J., Sausville, E.A., Battey, J. Comparison of amplified and unamplified c-myc gene structure and expression in human small cell lung carcinoma cell lines. Cancer Res. 1986; 46:2050-2055.

Shimizu, K., Bimbaum, D., Ruley, M.A., et al. Structure of the Ki-ras gene of the human lung carcinoma line Calu-1. Nature 1983; 304:497-500.

Shore, S.K., Bacheler, L.T., deRiel, J.K., Barrows, L.R., Lynch, M. Cloning and characterization of a rat-specific repetitive DNA sequence. Gene 1986; 45:87-93.

Skuse, G.R., Rowley, P.T. Tumor suppressor genes and inherited predisposition to malignancy. Seminars in Oncology 1989; í::128-137.

Southern, E.M. Detection of specific sequences among DNA fragments separated by gel electrophoresis. J. Mol. Biol. 1975; 98:503-517.

Stampfer, M.R., Bartley, J.C. Induction of transformation and continuous cell lines from normal mammary epithelial cells after exposure to benzo[a]pyrene. Proc. Natl. Acad. Sci. USA. 1985; 82:2394-2398.

Stanbridge, E.J.K., Der, CJ., Doersen, C.J., Nishimi,R.Y., Peehl, D.M., Weissman, B.E., Wilkinson, J.E. Human Cell Hybridgs: Analysis of Transformation and Tumorigenicity. Science. 1982; 215:252-259

Stanton, L.W., Watt, R., Marcu, K.B. et al. Translocation, breakage and truncated transcripts of c-myc oncogene in murine plasmacytomas. Naure. 1983; 303:401.406.

Stewart, T.A., Pattengale, P,K., Leder, P. Spontaneous mammary adenocarcinomas in transgenic mice that carry and express MTV/myc fusion genes. Cell 1984; 38:627-37.

Stranden, E., Radon in dwellings and lung cancer - a discussion. Health Phys. 1980; 38:301-306.

Sukumar, S., Notario, V. Martin-Zanca, D. et al. Induction of mammary carcinomas in rats by nitroso-methylurea involves malignant activation of H-ras-1 locus by single point mutations. Nature. 1983; 306:658-661.

Sun, N.C., Chu, E. HY., Chang, C.C. Staining method for the banding pattern of human mitiotic chromosomes. Mamm. Chromosome News Lett. 1973; 1:26-28.

Sutherland, B.M., Bennett, P.V. Transformation of human cells by DNA transfection. Cancer Res. 1984; 44:2769.

Svrivatsan, E.S., Benedict, W.F., Stanbridge, EJ. Implication of chromosome 11 in the suppression of neoplastic expression in human cell hybrids. Cancer Res. 1986; 46:6174-9. 
Tabin, C.J., Bradley, S.M., Bargmann, C.I. et al. Mechanism of activation of a human oncogene. Nature. 1982; 300:143-149.

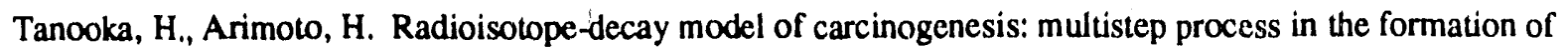
original single tumor cells induced by 3-Methylcholanthrene in mice. Gann. 1984; 75:126-129.

Taparowski, E., Suard, Y., Fasano, O., et al. Activation of T2. 3 bladder carcinoma transforming gene is linked to a single amino acid change. Nature 1982; 300:762-5.

Taya, Y., Hosogai, K., Hirohashi, S. et. al. A novel combination of K-ras and myc amplification accompanied by point mutational activation of $\mathrm{K}$-ras in a human lung cancer. EMBO, J. 1984; 3:2943-2946.

Thomas, D.C., McNeill, K.G., Dougherty, C. Estimates of lifetime lung cancer risks resulting from Rn progeny exposure. Health Phys. 1985; 49:825-846.

Vogel, A., Risser, R., Pollack, R. J. Cell. Physiol. 1973; 82:181-188.

Wagoner, J.K., Archer, V.E., Lundin, F.E. et al. Radiation as the cause of lung cancer among uranium miners. N. Engl. J. Med. 1965; 273:181-188.

Walen, K.H. Anchorage independent growth of SV40 transformed human epithelial cells from amniotic fluids: differences within and among cell donors. In Vitro 1982; 18:203-12.

Ward, J.F. The yield of DNA double-strand breaks produced intracellularly by ionizing radiation; a review. Int. J. Radiation Biology 1990; 57:1141-1150.

Weinberg, R.A. Oncogenes, antioncogenes, and the molecular bases of multistep carcinogenesis. Cancer Research $1989 ; 49: 3713-3721$.

Weinstein, I.B. Cell culture studies on the mechanism of action of chemical carcinogens and tumor promoters. Carcinog-Compr-Surv. 1985; 10:177-187.

Weiss, H., Strauss, A. and Lee, R. The temperature dependence of cellular radiation sensitivity as a method of investigating mechanisms of inactivation. Rad. Prot. Dosimetry 13, 181-184, 1985.

Wong, A.J., Ruppert, J.M., Eggleston, J. et al. Gene amplification of c-myc and N-myc in small cell carcinoma of the lung. Science. $1986 ; 233: 461-464$.

Yang, C.A., Tobias, E.A., et al. Enhancement effecis of high-energy neon particles on the viral transformation of mouse C3H10T $1 / 2$ cells in vitro. Rad. Res. 1980; 81:208-223.

Yang, T.C., Tobias, C.A. Neoplastic cell transformation by energetic heavy ions and its modification with chemical agents. Adv. Space Res. 1984; 4:207-218.

Yang, T.C., Craise, L.M., Mei, M.T. et al. Neoplastic cell transformation by heavy charged particles. Radiat. Res. 1985; 104:S-177-S-187.

Yoakum, G.H., Lechner, J.F., Gabrielson E.W. et al. Transformation of human bronchial epithelial cells transfected by Harvey ras oncogene. Science. 1985; 227:1176-79.

Yoshimoto, K., Shiraishi, M., Hirohashi, S. et al. Rearrangement of the c-myc gene in two giant cell carcinomas of the lung. Jpn. J. Cancer Res. 1986; 77:731-735. 

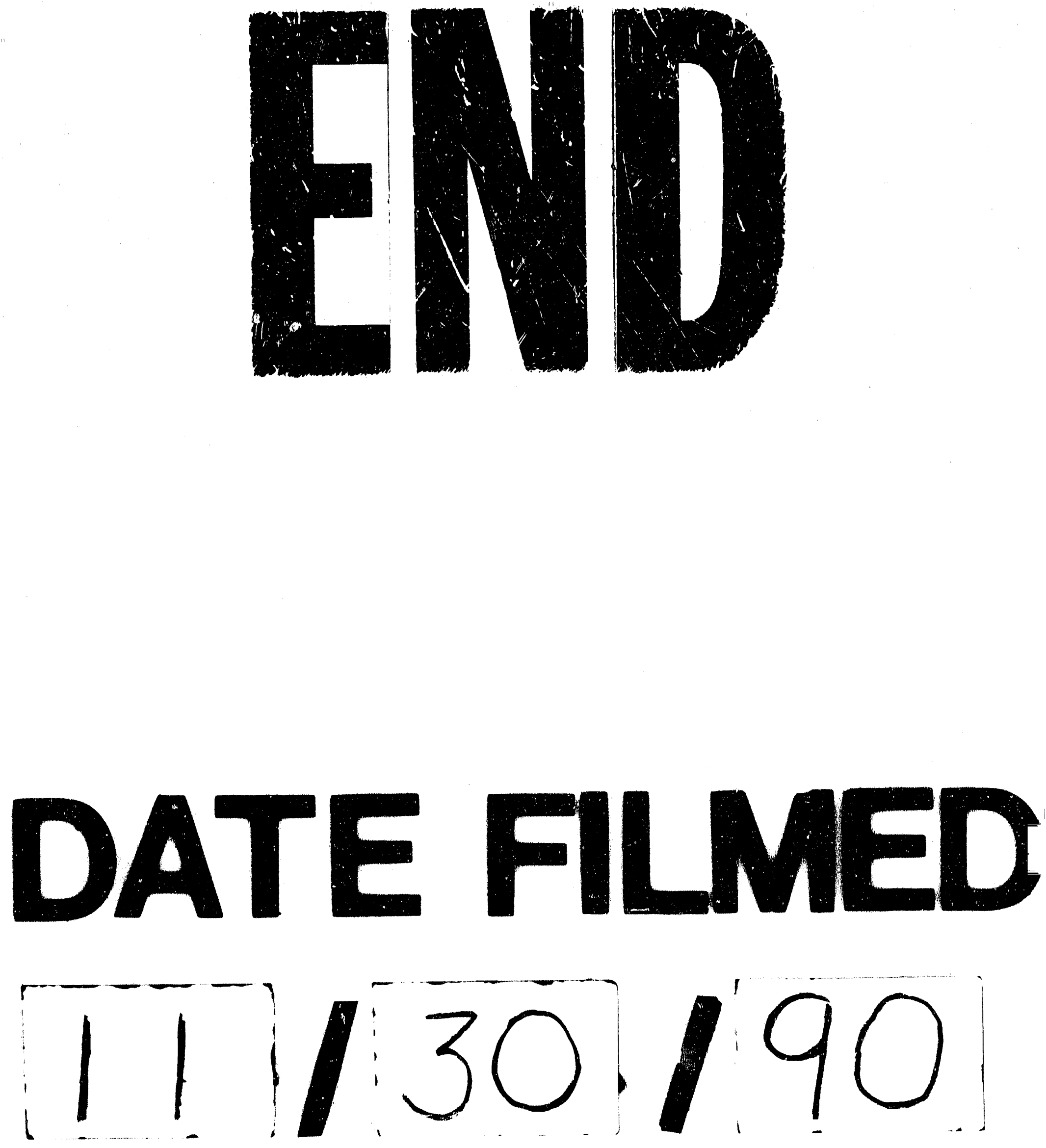
